\title{
THE ICE OF CROWN PRINCE GUSTAV CHANNEL, GRAHAM LAND, ANTARCTICA
}

\author{
By Alan ReEce \\ (Late Falkland Islands Dependencies Survey)
}

\begin{abstract}
The author describes the ice in Crown Prince Gustav Channel on the east coast of Graham Land,

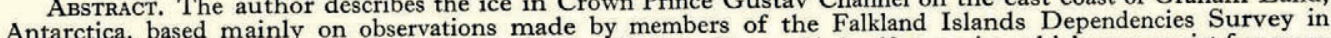
Antarctica, based mainly on observations made by members of the Falkand lslands Dependencies ice which may persist for more I $945-48$. He considers that the ice in the northern half of the the same origin as the Larsen Shelf Ice. He concludes that this shelf ice in the southern part of the Channel is part of the Larsen Shelf Ice.
\end{abstract}

Crown Prince Gustav Channel is situated on the east coast of Graham Land, between James Ross Island and Trinity Peninsula (the northernmost part of Graham Land). It is approximately roo miles $\left(\mathrm{r} 60 \mathrm{~km}\right.$.) long and $5^{-10}$ miles $\left(8-16 \mathrm{~km}\right.$.) wide. Nordenskjöld ${ }^{10}$ discovered the Channel and was the first to travel through it in October I902. Ellsworth flew over the area in 1935, but the second visit on the ground was not made until August 1945, when a sledging party from Hope Bay under Taylor travelled along the Channel from north to south. Since then it has been frequently visited by surveying parties from the F.I.D.S. base at Hope Bay. The author visited the northern half of the Channel almost every month between May 1946 and January 1947 and had many opportunities to observe it from the Trinity Peninsula plateau.

For descriptive purposes the Channel may be divided into a northern part from Duse Bay to Persson Island and a southern part from Persson Island to Cape Longing, see map opposite.

\section{Duse Bay to Persson Island}

Seen from the plateau on Trinity Peninsula (5000 feet; $1524 \mathrm{~m}$.), the northern part of the Channel appears as a level, unbroken expanse of sea ice containing many bergs and some pressure ridges curving out from the coast. The only direct measurement of thickness was made near Long Island in July 1948 , when $\mathrm{r} \cdot 5 \mathrm{~m}$. of ice was overlain by $0.9 \mathrm{I} \mathrm{m}$. of snow, the whole section of 2.4I $\mathrm{m}$. being made up as follows :

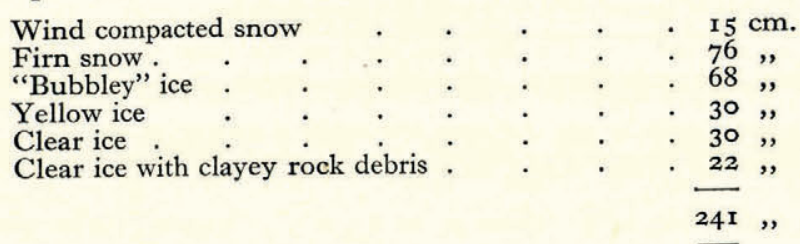

The position of the sea-level in fissures in other parts of the Channel confirms that the ice is generally $0.9-2 \cdot 4 \mathrm{~m}$. thick, overlain by varying depths of snow.

From about early May until the end of October, the ice is covered by snow with very few bare patches. As November advances and strong sun, together with thawing temperatures, becomes more frequent, a mass of water and slushy snow forms on the impervious ice. At this stage the overlying snow crust may be strong enough to travel over, but as further thawing takes place, the whole depth of snow is converted into a morass. Eventually the water finds cracks in the ice through which it can escape, and drains away in swift running streams. In a few areas, however, the water is drained away before it rises high enough to saturate the overlying crust, and the snow surface remains comparatively dry. During the latter half of the summer and early autumn, little or no accumulation of snow takes place, and the ice becomes very thin or may disappear altogether. In early April 1946 , areas of $5-8 \mathrm{~km} .^{2}$ showed open water with freely floating bergs, and equally 


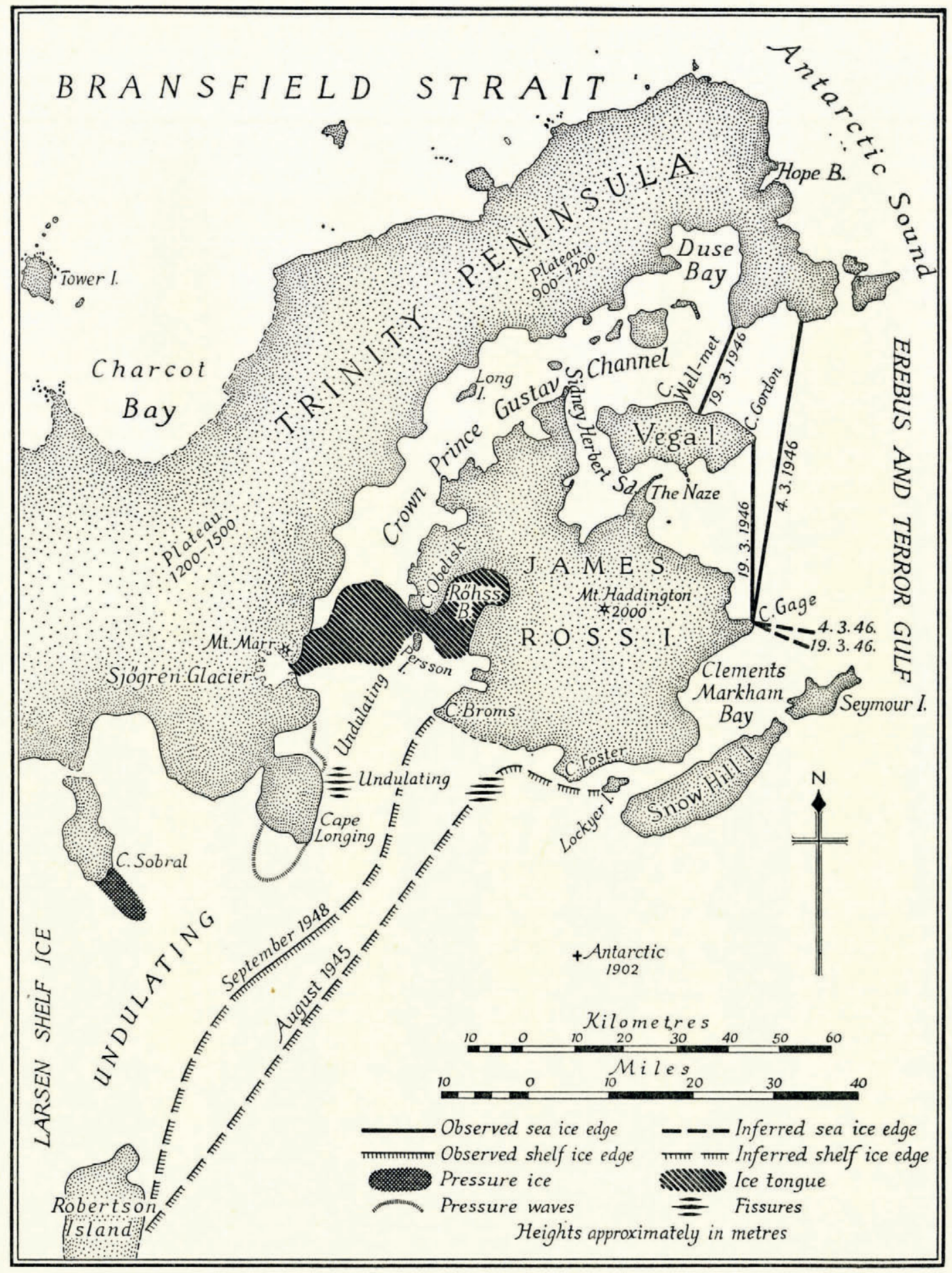


large areas were only some centimetres thick. The summer of $1947-48$ saw the break up of the major portion of the ice in the northern part of the Channel.

Flooding of the ice by sea water during a blizzard was experienced with nearly disastrous consequences. Some I. $5 \mathrm{~m}$. of snow had accumulated and depressed the ice to such an extent that sea water rose in an adjacent tide crack, and formed a slushy mixture with the lower half of the snow. In other areas traversed by cracks, one would sometimes break through the snow crust to find a mixture of snow and sea water on the ice below. Exactly similar phenomena have been described by Scott ${ }^{1}$ in McMurdo Sound, and by Tyrrell ${ }^{2}$ on the fresh water lakes of Canada.

Where the ice is bordered by land cliffs, or surrounds such cliffs on an island, a distinct ice foot and tide crack are developed, with a difference of up to $1.5 \mathrm{~m}$. between the floating and the fixed ice; these tide cracks have been found to be open even in mid-winter. In other places the Channel ice comes directly up to ice cliffs, and in these areas complex systems of pressure ridges usually exist. Sometimes no distinct coastal boundary can be found, the land ice gradually sloping down to sea level or a zone of compressed and hummocked ice separating the Channel ice from land ice.

Movement of the ice from north-west to south-east past Long Island was indicated by a series of pressure ridges on the north-west side of the island in contrast with the ice foot and tide crack on the south-east side. Where the tide crack met the pressure ridges at the north-east end, a fissure, at least $180 \mathrm{~m}$. long and up to nearly a metre wide, extended in a direction at right angles to the coast.

The limit of the ice edge across Erebus and Terror Gulf was kept under occasional observation and was found to retreat approximately $25 \mathrm{~km}$. at its southern end and $3 \mathrm{~km}$. at its northern end during 1946 , the ice lost during that period being about $285 \mathrm{~km} .{ }^{2}$. In November 1947 it was found that the sea had penetrated into the western end of Sidney Herbert Sound and by April 1948 most of the ice in the northern part of the Channel had broken up.

The bergs are generally gathered together in groups, being most closely packed in the bays of the mainland. They may be as much as nine or twelve metres high and are mostly of glacier type, but some tabular bergs, of about the same size, were found in Sidney Herbert Sound. In summer open water was often found surrounding the bergs. Near The Naze, on James Ross Island, Lamb 3 describes a sheared zone at the edge of the ice cliffs of James Ross Island with open water between the calved ice blocks. He also mentions frozen-in bergs near to a glacier that have portions of the glacier's moraine on them, proving them to be of local origin. Open water between the Channel ice and the land ice has also been observed in Duse Bay in May, and at Long Island in December; in the latter case it was about $3 \mathrm{~m}$. wide.

\section{Persson Island to Cape Longing}

From the Sjögren Glacier a large ice tongue protrudes across the Channel to Persson Island. This was discovered by Taylor in August $\mathbf{1 9 4 5}$, and is described by Lamb as having huge undulations of ice rifted in places and containing some old embedded blocks of glacier ice with morainic blocks. This ice sloped imperceptibly up onto the land and downwards to the sea ice. On opening up the Sjögren Glacier the party saw about four large glaciers streaming down from the highland plateau. Lamb concluded that the pressure set up by these caused the ridges, chasms and undulations he had encountered. Where the party crossed the ice tongue it rose in places to over $30 \mathrm{~m}$. above sea level. Francis ${ }^{4}$ reported it as generally $\mathrm{I}_{5}-20 \mathrm{~m}$. high. He also observed rock outcrops $3.6 \mathrm{~m}$. above the snow surface extending eastwards across the channel from Mt. Marr.

Another ice tongue protrudes from Röhss Bay, James Ross Island, towards Persson Island. Taylor ${ }^{5}$ noted undulations, the absence of tide cracks along what should have been the shore, and that his party had reached a height of $18 \mathrm{~m}$. They concluded that "this was all glacier ice."

South of these tongues at Persson Island the character of the ice is different from that to the 
north and Russell 6 describes it thus: "the surface was undulating continuously to a varying extent. At times the undulations were very gradual, having crests about half a mile $(0.8 \mathrm{~km}$.) apart, and just enough variation in height for one sledge party to lose sight of the other-probably IO-I $5 \mathrm{ft}$. $(3-5 \mathrm{~m}$.). At other times the crests were closer together, with a variation in height of up to $50 \mathrm{ft}$. (I $5 \mathrm{~m}$.)." He concludes that "the area appears to be composed of thin shelf ice," into which protrudes the Sjögren Glacier. James's ${ }^{7}$ map of the ice conditions in this area supports the conclusion that it is not normal sea ice since no bergs are shown.

\section{Discussion}

Nordenskjöld considered that the whole of the ice in the Channel, both north and south, was landfast sea ice and he does not show it as a feature of his map ${ }^{8}$ although he does suggest that the ice north of Robertson Island is shelf ice in the process of formation (p. 164-68). It will be clear from the above that although the ice in the northern part of the Channel is landfast sea ice, south of the ice tongues it is more in the nature of shelf ice.

\section{The northern ice of Crown Prince Gustav Channel}

The sea ice in the northern portion was observed to persist for two summers, $1945-46$ and 1946-47, but during the third summer, 1947-48, the sea broke through from Erebus and Terror Gulf to the east coast of Trinity Peninsula. Although the Channel was not observed in the summer of $1944-45$, the section through the ice made in July I 946 indicates that the ice had then persisted through one summer, $1945^{-46}$, and was now in its second winter. This is shown by the presence of a band of yellow ice representing one summer thaw period.

The sequence of events that will follow the I $947-48$ break-up are uncertain, but there is ample evidence to show that it is not the first time this has occurred. The presence of wave-cut cliffs around the islands and mainland of the northern part of the Channel, a penguin rookery on one of these islands, the numerous bergs and the sea ice section, are evidence of former occurrences of open water in this area. From April to the end of August I 948 open water and pack ice were observed in Erebus and Terror Gulf and the northern end of the Channel, and the break-up of the landfast sea ice, which had begun in the preceding summer, continued. From September to the end of 1948 , when observations ceased, the pack became frozen together but occasional pools of open water still persisted and the area was never really safe for sledging. It would seem unlikely that this sea ice withstood the r $948-49$ summer and it may be that an exceptional season will have to be experienced before such persistent landfast sea ice is again produced. On the other hand, the exceptional condition may be that in which the sea ice breaks up in summer. From the information at present available it appears most likely that the two conditions alternate over a period of unknown length; one in which the northern part of the Channel consists of landfast sea ice in both summer and winter, and the other in which landfast sea ice is present in winter but breaks up in the following summer. Further observations in this area may be able to establish some periodicity in these conditions.

A word of explanation with regard to the numerous and often densely packed bergs must be given here. Some of these bergs, the larger tabular bergs especially, must have originated from areas outside Crown Prince Gustav Channel, but it is probable that many if not all of the others have calved from the adjacent ice cliffs without a general break-up of the ice having occurred. From Lamb's description of the open water found at the base of the ice cliffs of James Ross Island and similar observations in Duse Bay, it can be seen that locally calved bergs floating there would be frozen in during the ensuing winter, and would then be gradually carried out with general movement of the ice. It is by such a process that the dense packing of bergs of local origin in Duse and other bays can best be explained. 


\section{The southern ice of Crown Prince Gustav Channel}

The origin of the ice in the southern part of the Channel is, presumably, the same as that of the Larsen Shelf Ice which Nordenskjöld accounted for by the accumulation of snow upon sea ice. $\mathrm{He}$ considered that shoals and islands played an important part in making the coast suitable for the retention of sea ice and the subsequent formation of shelf ice. There is no evidence that shoals play any part in retaining the sea ice in the northern part of the Channel, although James Ross, Vega and other smaller islands do so. The undulating nature of the ice in the southern part of the Channel suggests the presence of shoals or low islands. This appears to be the cause of the difference between the two types of ice in the Channel. That in the north is landfast sea ice which owes its persistence through more than one season to the presence of islands; that in the south is shelf ice of the same type and origin as the Larsen Shelf Ice although perhaps less thick. This is mainly due to the presence of shoals although islands are also there.

\section{Relationship with the Larsen Shelf Ice}

It remains to be considered what relationship exists between the ice of Crown Prince Gustav Channel and the Larsen Shelf Ice. Nordenskjöld 8 terminated the Larsen Shelf Ice quite abruptly by an ice wall running north from Robertson Island to the mainland, with a second higher wall, running west, some $80 \mathrm{~km}$. further south. Priestley ${ }^{9}$ used it in his classification as the type locality for shelf ice "type b," defined as "originally formed mainly or entirely by the accumulation of snow upon sea ice which has persisted for several seasons."

Nordenskjöld's 10 account of his sledge journey on the Larsen Shelf Ice (called by him "Lower Ice Terrace"), and the voyage of the Antarctic along its face, throw doubt on whether its seaward edge terminates in ice cliffs as shown on his map. In the furthest south position of the Antarctic Nordenskjöld estimated that the ice cliffs were $40 \mathrm{~m}$. high, but later in the day, when they again approached the land, he says: "Strangely enough we found no barrier here, but as far as the eye could reach, a low, level surface of ice stretched inwards towards the land." Again during the sledge journey he appears to have climbed up and down several times after surmounting the ice wall, and says, after three days: "I had not made up my mind whether it was old sea ice or not that we were on."

Larsen 11 describes the seaward edge of his more southern barrier as being greatly indented and although high in some places, low enough in others to land on from the ship.

From Cape Longing Taylor says: "To the south we looked in vain for signs of the barrier ice cliffs, but in front of all the islands and nunataks between Robertson and Lindenberg Islands lay a very disturbed zone, clearly to be seen even at this great distance, and many lesser undulations between this area and us." Two journeys made in the area of Robertson Island during 1947 confirm that no ice cliffs exist there.

From this evidence I conclude that no essential difference can be drawn between the Larsen Shelf Ice and the ice in the southern part of the Channel. Also that conditions north of Robertson Island are similar to those south of it, except that as Graham Land widens out to the south more vigorous glaciers descend to the east coast producing bigger and more active ice tongues. These would give rise to steep ice cliffs locally at the seaward edge and produce the surface travelled over by Nordenskjöld and the F.I.D.S. survey party under Elliot. ${ }^{12}$ The 40 metre high ice cliffs reported by Nordenskjöld may have been an ice tongue, and Taylor's description suggests it was an ice tongue Nordenskjöld climbed near Robertson Island; his second ice wall may also have been of that nature. "The canal-like crevasses" $20 \mathrm{~m}$. wide "and almost as deep, which seemed to run in towards the land" 10 match Taylor's and Lamb's accounts of the approach to the Sjögren Glacier tongue. 
Thus the Larsen Shelf Ice now extends north from Robertson Island into the southern end of the Channel. The position of its eastern edge, north of Robertson Island, is doubtful, but Taylor's party must have crossed it on their journey from Cape Longing to Snow Hill Island. They crossed some rifts when near Cape Foster which Russell says "might possibly open up and act as tide cracks," and it is most likely that the border between shelf and sea ice was somewhere in this area. In mid-September 1948 the edge of the shelf ice was observed to have broken back westwards to within about $24 \mathrm{~km}$. of Cape Sobral.

In conclusion, Larsen Shelf Ice, at the present time, extends as one continuous homogeneous sheet of varying thickness, north-eastwards from its previously mapped northern limit near Robertson Island to the Sjögren Glacier tongue in the southern part of the Channel. Its seaward edge, whose position obviously varies from year to year, may be taken to run from Robertson Island generally north-east towards James Ross Island. North-east of the Sjögren Glacier tongue landfast sea ice covers the northern part of the Channel and often persists for several seasons.

I am indebted to Mr. J. M. Wordie, St. John's College, Cambridge, for much helpful criticism of this paper and also for the interpretation of the sea ice section. I also acknowledge with thanks the permission of the Colonial Office to publish this report.

$M S$. received I September 1949

\section{R E F E R E N E S}

I. Scott, R. F. The Voyage of the Discovery. London: Smith Elder \& Co., 1905, Vol. 1, p. 366-68.

2. Tyrrell, J. B. Ice on Canadian Lakes. Transactions Canadian Institute, Vol. 9, 1913, p. 13-22.

3. Lamb, I. M. 1945. Personal diary. (Unpublished.)

4. Francis, S. J. 1948. Survey and Topographical Report, Hope Bay to Marguerite Bay. (Unpublished.)

5. Taylor, A. I945. Personal diary. (Unpublished.)

6. Russell, V. I. I945. Glaciological Report for Sledge Journey. 8 August-I I September 1945. (Unpublished.)

7. James, D. 1945. Sea Ice Report for Sledge Journey. 8 August-I I September, 1945. (Unpublished.)

8. Nordenskjöld, N. O. G. Die Expedition und ihre geographische Tätigkeit. Wissenschaftliche Ergebnisse d. Schwedischen Südpolar Expedition $190 \mathrm{I}-3$. Stockholm, 1920, Band $\mathrm{x}$, Lief. $\mathrm{I}, 232$ pages.

9. Wright, C. S. and Priestley, R. E. British (Terra Nova) Antarctic Expedition 1910-1 3. Glaciology. London: Harrison \& Sons, I922.

10. Nordenskjöld, N. O. G. and Anderson, J. G. Antarctica. London: Hurst \& Blackett, 1905.

Ix. Larsen, C. A. The Voyage of the Fason to the Antarctic regions. Abstract of journal kept by Capt. C. A. Larsen. Geographical Fournal, Vol. 4, No. 4, 1894, p. 333-44.

12. Elliot, P. K. Comprehensive Report on Work at Hope Bay 1948. 1949. (Unpublished.)

The manuscript of unpublished material is at present in the care of the "Discovery" Investigations, Room I 8, Queen Anne's Chambers, 4I Tothill Street, London, S.W.r.

\section{THE LARSEN SHELF ICE}

\section{By Douglas Mason}

(Late Falkland Islands Dependencies Survey)

Paper read at a Meeting of the Society on 17 November 1949

\footnotetext{
ABSTRACT. Description of that part of the Larsen Shelf Ice traversed by the author when taking part in a sledging expedition which reached lat. $74^{\circ} 42^{\prime}$ S., manned jointly by members of the Falkland Islands Dependencies Survey and the Ronne Antarctic Research Expedition 1946-48.
}

THE Larsen Shelf Ice forms one of the two great areas of shelf ice in the Weddell Sea; it extends, in a belt varying from ro to 100 miles $(16-160 \mathrm{~km}$.) wide, down the coast on the west side of the Weddell Sea from near the northern tip of Graham Land, in lat. $63^{\circ} 45^{\prime} \mathrm{S}$. for about $65^{\circ}$ miles $\left(1046 \mathrm{~km}\right.$.) to a peninsula in lat. $73^{\circ} \mathrm{S}$. Two other smaller sections of shelf ice, one about 80 miles $(\mathrm{r} 28 \mathrm{~km}$.) long, and the other filling a narrow inlet, exist on the western side of the Weddell Sea south of the Larsen Shelf Ice; and then in lat. $75^{\circ} \mathrm{S}$. the Filchner Shelf Ice extends southeastwards to Coats Land and forms the southern limit of the Weddell Sea. 